\title{
Performa Produksi Telur pada Ayam Ketarras Generasi Kedua dengan Bobot Badan yang Berbeda
}

\author{
Ahmad Saleh Harahap ${ }^{1 *}$, Kususiyah ${ }^{1}$, Amir Husaini Karim Amrullah ${ }^{1}$ \\ ${ }^{1}$ Jurusan Peternakan Fakultas Pertanian Universitas Bengkulu \\ Jalan W.R. Supratman, Kandang Limun, Bengkulu 38371 \\ *Penulis korespondensi : ahmadsaleh@unib.ac.id
}

Artikel ini diterima (received): 19 Maret 2021; dinyatakan disetujui (accepted): 28 Mei 2021; terbit (published): 30 Mei 2021. Artikel ini dipublikasi secara daring pada https://ejournal.unib.ac.id/index.php/buletin_pt/index

\begin{abstract}
Abstrak
Penelitian ini bertujuan untuk melihat performa produksi telur pada ayam ketarras dengan bobot badan yang berbeda. Penelitian ini menggunakan 30 ekor ayam betina Ketarras umur 11 sampai 13 bulan. Penelitian dilaksanakan di Commercial Zone and Animal Laboratory (CZAL) Jurusan Peternakan, Fakultas Pertanian, Universitas Bengkulu. Kandang yang digunakan adalah kandang batteray yang merupakan kandang individu. Ransum yang diberikan dengan komponen konsentrat khusus ayam petelur, dedak dan jagung giling. Paramater yang diambil ketika penelitian adalah konsumsi ransum, produksi telur, bobot telur, persentase produksi telur dan konversi ransum. Rancangan yang digunakan adalah Rancangan Acak Lengkap dengan perlakuan bobot badan. Perlakuan Penelitian yaitu P1 (Bobot badan 1000-1100 gram), P2 (1200-1300 gram) dan P3 (14001500 gram). Data yang diperoleh dianalisis secara analisis ragam. Hasil penelitian memperlihatkan adanya perbedaan pada konsumsi ransum, tetapi tidak pada produksi telur, bobot telur, persentase produksi telur dan konversi ransum. Konsumsi ransum P2 dan P3 lebih tinggi dibandingkan P1. Jumlah telur yang dihasilkan dari 30 ekor selama 3 bulan pengamatan sebesar 1.728 butir dengan rataan produksi telur perbulan per ekor adalah 19 butir/ekor/bulan. Secara keseluruhan bobot telur yang diperoleh sebesar $\mathbf{4 8 . 2 2}$ gram. Sementara persentase produksi telur secara keseluruhan yang diperoleh mencapai 63.30 \%. Hasil penelitian ini disimpulkan bahwa ayam Ketarras generasi kedua umur 11-13 bulan dengan bobot tinggi memiliki tingkat konsumsi ransum yang tinggi. Selanjutnya performa produksi, persentase produksi, bobot telur dan konversi ransum memiliki performa yang sama dengan bobot badan yang berbeda pada ayam Ketarras.
\end{abstract}

Kata kunci : Ayam ketarras, persilangan, performa produksi telur, bobot telur.

\section{Pendahuluan}

protein hewani yang sangat familiar dan digemari oleh masyarakat. Hal ini dikarenakan telur sangat mudah ditemukan dan harga di pasar yang sangat terjangkau. Untuk memenuhi kebutuhan telur di pasar diperlukan adanya produsen dalam hal ini peternak ayam yang menghasilkan telur sesuai permintaan pasar. Persilangan ayam Arab jantan dengan ayam Ras betina menghasilkan ayam yang diberi nama Arras (Nur, 2016). Ambarwati (2016) melaporkan telur ayam Arras masih dominan menyerupai telur ayam Ras dilihat dari ukuran dan warnanya.

Persilangan antara ayam Arras betina dengan ayam Arab dilakukan untuk mengurangi warna coklat pada kerabang telur karena dengan menambahkan genetik ayam Arab diharapkan warna kerabang telur akan menyerupai telur ayam Kampung. Hasil persilangan ayam Arras betina dengan ayam Arab jantan diberi nama Ketarras (keturunan Arab dan Arras). Hasil penelitian Saputra (2018) menyatakan rataan ukuran bobot telur ayam Ketarras 46,70 gram, Surnoto (2018) 
menyatakan warna telur ayam Ketarras 90,96\% berwarna putih kecoklatan. Marliya (2017) melaporkan bahwa akseptabilitas konsumen terhadap telur ayam Ketarras sebagai telur ayam Kampung $86,21 \%$. Lebih lanjut Marliya (2017) menyatakan, telur ayam Ketarras sudah bisa diterima dan dihargai sama dengan telur ayam Kampung.

Hasil persilangan ayam arab dengan ayam ras petelur yaitu ayam Arras (50\% ayam Arab $50 \%$ ayam Ras petelur) menunjukkan bahwa produksi telurnya cukup baik, namun warna kerabang telur ayam Arras yang dihasilkan lebih dominan menyerupai warna kerabang telur ayam Ras, sehingga masih mempunyai nilai harga jual yang lebih rendah dibanding dengan harga telur ayam Kampung. Agar dominasi warna kerabang telur dari ayam Ras petelur yang dihasilkan berkurang, maka ayam Arras perlu disilangkan kembali dengan ayam Arab, hasil persilangan ini dinamakan ayam Ketarras (keturunan dari ayam Arab jantan dengan ayam Arras betina) yang memiliki darah $25 \%$ ayam Ras petelur coklat dan $75 \%$ ayam Arab.

Salah satu faktor yang mempengaruhi performa suatu ayam petelur adalah bobot badan dari ternak tersebut. Sifat tersebut akan diwariskan kepada keturunannya, dalam hal ini adalah anakan ayam Ketarras. Berdasarkan hal tersebut perlu dikaji bagaimana pengaruh bobot badan terhadap performa produksi telur dari ayam Ketarras generasi ke-2.

\section{Bahan dan Metode}

Penelitian ini dilaksanakan selama 3 bulan yaitu pada bulan September sampai Nopember 2020 di CZAL Jurusan Peternakan Fakultas Pertanian Universitas Bengkulu. Pemeliharaan dilakukan dengan jumlah ayam Ketarras betina yang digunakan adalah 30 ekor umur 11-13 bulan. Kandang yang digunakan adalah kandang individu (batteray). Penelitian ini dengan 3 perlakuan yaitu P1 (Bobot badan 1000-1100 gram), P2 (1200-1300 gram) dan P3 (1400-1500 gram). Pemberian ransum akan diberikan setiap harinya pada ayam Ketarras sebanyak 120 gram (Hidayatullah, 2018 dan Murdiono 2018). Pemberian ransum dilakukan dua kali sehari, pada pagi hari pukul 07.00 WIB dan sore hari pukul 16.00 WIB. Penghitungan konsumsi ransum dilakukan dengan menimbang sisa ransum setiap minggu. Air minum diberikan secara ad libitum. Kandungan nutrisi bahan penyusun ransum, formulasi ransum dan kandungan nutrisi ransum dapat dilihat pada Tabel 1. dan Tabel 2. Koleksi dan penimbangan telur dilakukan secara kumulatif setiap hari dengan timbangan digital.

Tabel 1. Kandungan nutrisi bahan penyusun ransum

\begin{tabular}{|c|c|c|c|c|c|c|}
\hline Bahan Penyusum & PK (\%) & $\begin{array}{c}\mathrm{ME} \\
\text { (kkal/kg) }\end{array}$ & SK (\%) & $\begin{array}{c}\text { Lemak } \\
(\%)\end{array}$ & $\mathrm{Ca}(\%)$ & $\mathrm{P}(\%)$ \\
\hline Jagung Giling & $8.90^{\mathrm{b}}$ & $3321.00^{\mathrm{b}}$ & $2.50^{\mathrm{b}}$ & $4.00^{\mathrm{b}}$ & $0.29^{a}$ & $0.44^{\mathrm{a}}$ \\
\hline Dedak Halus & $11.90^{b}$ & $1856.49^{a}$ & $10.00^{b}$ & $12.00^{b}$ & $0.37^{\mathrm{a}}$ & $0.92^{\mathrm{a}}$ \\
\hline$K_{L} K^{c}$ & 33.00 & 2700.00 & 9.83 & 6.37 & 10.87 & 1.28 \\
\hline Keterangan : & $\begin{array}{l}\text { siyah dan } \\
\text { di et al. ( } \\
\text { KLK (Kon }\end{array}$ & $\begin{array}{l}\text { aruddin (20 } \\
\text { 5) } \\
\text { rat Layer Kr }\end{array}$ & & & & \\
\hline
\end{tabular}

Tabel 2. Formulasi Ransum dan Kandungan Nutrisi Ransum

\begin{tabular}{lccccccc}
\hline Bahan Penyusum & $\begin{array}{c}\text { Proporsi } \\
(\%)\end{array}$ & PK (\%) & $\begin{array}{c}\text { ME } \\
(\mathrm{kkal} / \mathrm{kg})\end{array}$ & SK (\%) & $\begin{array}{c}\text { Lemak } \\
(\%)\end{array}$ & Ca (\%) & P (\%) \\
\hline Jagung Giling & 40.00 & 3.56 & 1328.40 & 1.00 & 1.60 & 0.12 & 0.18 \\
Dedak Halus & 29.00 & 3.45 & 538.38 & 2.90 & 3.48 & 0.11 & 0.27 \\
KLK & 31.00 & 10.23 & 837.00 & 3.05 & 1.97 & 3.37 & 0.40 \\
\hline Total & 100.00 & 17.24 & 2703.78 & 6.95 & 7.05 & 3.59 & 0.84 \\
\hline
\end{tabular}


Rancangan Penelitian

Rancangan pada penelitian ini adalah rancangan acak lengkap dengan 3 perlakuan dengan 10 ulangan. Perlakuan yang diberikan berdasarkan bobot badan yaitu P1 (Bobot badan 1000-1100 gram), P2 (1200-1300 gram) dan P3 (1400-1500 gram). Setiap ulangan menggunakan 1 ekor ayam Ketarras.

\section{Variabel yang diamati}

Variabel ayang diamati pada penelitian ini adalah konsumsi ransum, produksi telur, persentase produksi telur, bobot telur dan konsumsi ransum.

\section{Analisa Data}

Data yang diperoleh disajikan berdasarkan rataan dan standar deviasi dan dianalisis menggunakan analisis ragam dengan aplikasi Minitab

\section{Hasil dan Pembahasan}

Penelitian yang dilakukan diperoleh datadata yang terdiri dari konsumsi ransum, produksi telur, persentase produksi telur, bobot telur dan konversi ransum. Hasil yang diperoleh pada masing-masing parameter ditabulasikan ke dalam Tabel.

Konsumsi ransum ayam Ketarras umur 11-13 bulan disajikan pada Tabel 3. Hasil analisi ragam menunjukkan bahwa bobot badan berpengaruh $(\mathrm{P}<0.05)$ terhadap konsumsi ayam Ketarras. Konsumsi ransum P2 dan P3 lebih tinggi dibandingkan P1. Hal ini menunjukkan bahwa bobot badan yang tinggi (P3) pada ayam Ketarras memiliki konsumsi yang tinggi juga.

Produksi telur dan rataan produksi telur dari September sampai Nopember 2020 disajikan pada Tabel 4. Hasil analisis ragam menunjukkan bahwa bobot badan tidak memengaruhi persentase produksi telur pada ayam ketarras generasi kedua $(P>0,05)$. Hal ini menunjukkan bahwa produksi telur pada masing-masing perlakuan bobot badan ayam Ketarras tidak beragam.

Produksi telur pada ayam ketarras secara kolektif pada semua kelompok bobot badan yang diamati mencapai 1728 butir dengan rataan produksi telur per bulan adalah 19 butir/ekor/bulan. Persentase produksi telur secara keseluruhan pada ayam Ketarras selama penelitian mencapai $63.30 \pm 11.55 \%$.

Tabel 3. Konsumsi Ransum ayam Ketarras umur 11-13 bulan

\begin{tabular}{cccc}
\hline Perlakuan & $\begin{array}{c}\text { Jumlah Konsumsi } \\
\text { selama 3 bulan }(\mathrm{g})\end{array}$ & $\begin{array}{c}\text { Rataan Konsumsi } \\
\text { (g/ekor/bulan) }\end{array}$ & Rataan Konsumsi (g/ekor/hari) \\
\hline P1 & 96066 & $3202.20^{\mathrm{a}} \pm 112.01$ & $106.74^{\mathrm{a}} \pm 3.69$ \\
P2 & 100605 & $3353.50^{\mathrm{b}} \pm 171.71$ & $111.78^{\mathrm{b}} \pm 5.66$ \\
P3 & 101754 & $3391.80^{\mathrm{b}} \pm 103.66$ & $113.06^{\mathrm{b}} \pm 3.42$ \\
\hline
\end{tabular}

Tabel 4. Jumlah Produksi Telur dan Rataan Produksi Telur Ayam Ketarras umur 11-13 bulan

\begin{tabular}{ccccc}
\hline Perlakuan & $\begin{array}{c}\mathrm{N} \\
\text { (ekor) }\end{array}$ & Jumlah Telur & $\begin{array}{c}\text { Rataan Produksi Telur } \\
\text { (Butir/ekor/bulan) }\end{array}$ & $\begin{array}{c}\text { Persentase Produksi Telur } \\
\text { (\%) }\end{array}$ \\
\hline P1 & 10 & 537 & 18 & $59.01^{\mathrm{a}} \pm 12.06$ \\
P2 & 10 & 624 & 21 & $68.57^{\mathrm{a}} \pm 11.89$ \\
P3 & 10 & 567 & 19 & $62.31^{\mathrm{a}} \pm 10.69$ \\
\hline Total & $\mathbf{3 0}$ & $\mathbf{1 7 2 8}$ & & $\mathbf{6 3 . 3 0 \pm 1 1 . 5 5}$ \\
Rataan & & $\mathbf{5 7 6}$ & $\mathbf{1 9}$ & \\
\hline
\end{tabular}


Tabel 5. Rataan Bobot Telur Telur dan konversi ransum Ayam Ketarras umur 11-13 bulan

\begin{tabular}{cccc}
\hline Perlakuan & $\mathrm{N}$ (ekor) & Bobot Telur $(\mathrm{g})$ & Konversi Ransum \\
\hline P1 & 10 & $47.81^{\mathrm{a}} \pm 2.49$ & $3.76^{\mathrm{a}} \pm 0.82$ \\
P2 & 10 & $48.03^{\mathrm{a}} \pm 2.88$ & $3.32^{\mathrm{a}} \pm 0.91$ \\
P3 & 10 & $48.82^{\mathrm{a}} \pm 2.79$ & $3.71^{\mathrm{a}} \pm 0.71$ \\
\hline Rataan & 30 & $\mathbf{4 8 . 2 2} \pm 2.72$ & $\mathbf{3 . 5 8}$
\end{tabular}

Bobot telur merupakan salah satu indikator performa yang dapat dilihat dalam beternak ayam petelur. Bobot telur ayam Ketarras generasi ke-2 yang diamati dapat dilihat pada Tabel 5. Hasil analisis ragam menunjukkan bahwa bobot badan tidak memengaruhi bobot telur pada ayam ketarras generasi kedua $(P>0,05)$. Hal ini menunjukkan bahwa bobot telur pada masing-masing perlakuan bobot badan tidak beragam. Bobot telur ayam Ketarras generasi ke-2 memiliki rataan keseluruhan yaitu $48.22 \pm 2.72 \mathrm{~g}$. Bobot telur ini lebih tinggi dibandingkan dengan bobot telur ayam Ketarras (generasi 1) umur 28-40 Minggu yaitu 46,7 g/butir (Kususiyah et al. 2020)..Ukuran telur ayam ketarras berdasarkan SNI termasuk dalam ukuran kecil karena memiliki bobot telur dibawah 50 gram. Berdasarkan SNI 3926:2008 : bobot telur yang dibawah 50 gram termasuk dalam kategori kecil, bobot telur 50 gram sampai dengan 60 gram termasuk kategori sedang, bobot telur lebih dari 60 gram termasuk kategori besar.

Bobot badan pada ayam Ketarras umur 1113 bulan generasi kedua menunjukkan tidak berpengaruh nyata $(P>0.05)$ pada Konversi ransum. Hal ini menunjukkan bahwa besarnya konsumsi ransum menghasilkan bobot telur yang sama dengan bobot badan yang berbeda. Konversi ransum pada ayam Ketarras generasi kedua pada P1 sebesar 3.76, P2 sebesar 3.32 dan P3 sebesar 3.71.

\section{Kesimpulan}

Hasil penelitian ini disimpulkan bahwa ayam Ketarras generasi kedua umur 11-13 bulan dengan bobot tinggi memiliki tingkat konsumsi ransum yang tinggi. Selanjutnya performa produksi telur, persentase produksi telur, bobot telur dan konversi ransum memiliki performa yang sama dengan bobot badan yang berbeda pada ayam Ketarras.

\section{Ucapan Terimakasih}

Ucapan terimakasih kepada PNBP Fakultas Pertanian Universitas Bengkulu yang telah mendanai kegiatan Penelitian Pembinaan Dosen tahun pendanaan 2020 Nomor 2403/UN30.11/PM/2020.

\section{Daftar Pustaka}

Ambarwati, N. 2016. Performans Keturunan Ayam Arab dengan Ayam Ras Petelur (Ayam Arras) Betona dan Ayam Arab Betina Umur 12 Minggu-Dewasa Kelamin. Program Studi Peternakan Fakultas Pertanian. Universitas Bengkulu. Bengkulu.

Gunawan, E., D. Kaharuddin, Kususiyah. 2018. Performans Keturunan Ayam Arras dengan Ayam Arab (Ayam Ketarras) Umur 2-12 Minggu. Jurnal Sain Peternakan Indonesia. 13 (1): $89-100$

Hartadi, H.S., Reksohardiprojo dan A.D. Tilman. 2005. Tabel Komposisi Pakan untuk Indonesia. Cetakanke IV. Universitas Gajah Mada. Yogyakarta

Hidayatullah, M.A., Kususiyah, dan D. Kaharuddin. 2018. Performans Ayam Ketarras pada Umur 2 Sampai 12 Minggu Berdasarkan Pola Warna Bulu. Jurnal Sain Peternakan Indonesia 13 (4) : 402:411.

Purnomo, D. J.. 2018. Performans Produksi Ayam Ketarras dan Ayam Arab Betina Umur 40-52 Minggu. Skripsi. Program Studi Peternakan Fakultas Pertanian. Universitas Bengkulu. Bengkulu.

Kususiyah, D Kaharuddin dan A. A. D. Surnoto. 2020. Performa Produksi Telur Ayam Ketarras dan Ayam Arab Umur 28 -40 Minggu. Buletin Peternakan Tropis. 1.(2): 4047 
Murdiono, H. T., D. Kaharuddin, dan Kususiyah. 2019. Performans Ayam Ketarras Pada Umur 12 Minggu Sampai Dewasa Kelamin Berdasarkan Pola Warna Bulu. Jurnal Sain Peternakan Indonesia 14(2) : 182-190

Nur, M. A. 2016. Performans pertumbuhan keturunan ayam arab dengan ayam ras petelur (ayam arras) dan ayam arab umur 2 - 12 minggu. Jurusan Peternakan Fakultas Pertanian Universitas Bengkulu

Saputra, M. A. 2018. Performans ayam Ketarras mulai dewasa kelamin sampai umur 28
Minggu. Jurusan Peternakan. Fakultas Pertanian. Universitas Bengkulu.

Standar Nasional Indonesia. 2008. Telur Ayam Konsumsi; SNI 3926:2008. Badan Standarisasai Indonesia, Bogor

Surnoto, A. A. D. (2018). Performans Produksi Telur Ayam Ketarras dan Ayam Arab Mulai Umur 28-40 Minggu. Program Studi Peternakan Fakultas Pertanian. Universitas Bengkulu. Bengkulu. 